\title{
Wild food plants of Remote Oceania
}

\author{
Will C. McClatchey* \\ Botanical Research Institute of Texas, 1700 University Drive, Fort Worth, Texas 76107, USA \\ Department of Botany, University of Hawai'i at Manoa, Honolulu, Hawai' 96822, USA \\ Environmental Studies Program, Texas Christian University, Fort Worth, Texas 76107, USA
}

\section{Abstract}

Agricultural societies partly depend upon wild foods. Relationships between an agricultural society and its wild foods can be explored by examining how the society responds through colonization of new lands that have not been previously inhabited. The oldest clear example of this phenomenon took place about 5000 years ago in the tropical Western Pacific at the "boundary" interface between Near and Remote Oceania. An inventory of wild and domesticated food plants used by people living along "the remote side of" that interface has been prepared from the literature. This was then assessed for the roles of plants at the time of original colonization of Remote Oceania. The majority of species are wild foods, and most of these are used as leafy vegetables and fruits. The wild food plants mostly serve as supplements to domesticated species, although there are a few that can be used as substitutes for traditional staples.

Keywords: Oceania, wild food plants, colonization, agriculture

\section{Introduction}

Human-plant co-evolutionary relationships have been documented for processes of wild plant food domestication into socially critical crops [1,2]. However, major "food" plants consumed by humans were first derived from plants that have co-evolved with other animals. The plants make use of the animal's food habits for pollination, seed dispersal, and other services. Other animals include grazers (such as cattle), browsers (such as deer), frugivores (such as monkeys and birds), and omnivores (such as pigs and rats).

Wild food plants contrast to those that were domesticated in that populations of domesticated plants have gone through a selection process, by humans, that has resulted in a change in their genetic structure that benefits humans [3]. Conversely, wild plants persist without need of any selection or tending by humans and have genetics that reflect their original coevolutionary relationships. In many parts of the world, wild relatives of domesticated plants exist side by side, or within short distances of their domesticated kin. Speculation about human development of agriculture from wild plants has been based on observations that agriculture developed from seeds left in dump heaps [4] and/or wet river camp sites [5]. The

\footnotetext{
*Email: wmcclatchey@brit.org
}

This is an Open Access digital version of the article distributed under the terms of the Creative Commons Attribution 3.0 License (creativecommons.org/licenses/by/3.0/), which permits redistribution, commercial and non-commercial, provided that the article is properly cited. implication is that humans brought wild plant materials to their homes or processing sites, much as squirrels or fruit bats might do, and then consumed less than all of the material collected, discarding material (seeds or other living parts) that could grow into new plants.

The process of transition from wild to domesticated remains vague. Some plants exist as persistent hangers-on in the shadow of humanity, while others are periodically brought near to the home to survive as captives. For the purposes of this paper, wild and domesticated are determined not by genetic changes in plants, but based on how humans interact with the plants. Those that are actively tended will be called domesticated, while those that are left to grow on their own, being ignored until needed for food, will be called wild. Plants that are generally cultivated, but sometimes survive on their own will be called feral when being ignored by humans.

This paper sets out to provide: (i) a brief inventory of wild foods used at the interface of geographic regions called Near and Remote Oceania and then; (ii) an assessment of the roles of these plants at the time of original colonization of Remote Oceania. Several background issues are presented first that set the context for understanding the environment, people, and plants. The colonization of Remote Oceania and the role of wild food plants is important because this is the most ancient known example of initial colonization of a part of the earth by an agricultural society.

\section{Wild foods}

Wild foods constitute the diet of traditional hunter-gathers although the details of how our ancestors lived and made decisions are controversial [6]. Human cultures that developed agricultural practices began to emphasize some plants (and animals) by investing more time in them. These plants became 
those that are cultivated. Uncultivated plants were still used for many purposes, including food. One of the uses of uncultivated plants has undoubtedly been for periods of insufficient production of cultivated plants. All cultures periodically experience some sort of food shortages [7] that require consumption of scarcity foods [8]. In the literature, these are often called "famine foods" even though starvation may not actually be associated very often with their consumption. These foods are typically produced from wild or feral plants. Probably it is better to sort foods into categories of preferred and secondary or alternative foods since this more accurately reflects what is seen in the world. In actual famine, starving people will eat almost anything. This paper is not about the foods eaten by starving people, but rather about the alternative foods, particularly those that are not cultivated and therefore may be called wild plant foods [9].

Cox [9] argues that alternative foods are consumed in patterns that mirror diets of normal times, serving as analogs of preferred foods. He uses two examples from Samoa (in Remote Oceania) to illustrate this. Cyrtosperma is a wild source of starchy rhizomes. It is an analog of cultivated Colocasia that also produces starchy rhizomes. Conversely, feral Metroxylon is a starch source (extracted from the stems) that is not eaten as an alternative food to Colocasia because it is dissimilar to the traditional diet pattern. He furthermore states that famine or alternative foods are likely to be introduced species and/or previous cultivars that were important in the past or in other prior locations.

Wild foods may be alternatives because they are less productive or require more difficult preparation. Preparation may involve longer cooking (higher fuel/time costs), removal of protective toxins (washing, cooking, peeling or abrading of toxic layers), or lengthy processing of more, smaller plant parts (such as seeds) to generate similar volumes of food. For example, aroids, such as Alocasia contain proteolytic enzymes that can cause severe irritation and tissue damage. These enzymes are denatured with heat so that cooking with steam is a common strategy for rendering the rhizomes and leaves edible [10] (it is common to find reports in the literature indicating that these must be cooked to destroy oxylate crystals. However, this is not supported by research [10]). Most varieties of Colocasia are easier to process than varieties of Alocasia rendering Alocasia as an alternative to Colocasia. A second example is processing of seeds from nuts. Terminalia catalpa L., Canarium indicum L., and Barringtonia edulis Seem., each have larger seeds that accumulate faster than their wild relatives of the same genera. Finally, among communities that do extract starch from plants such as Amorphophallus, Metroxylon, or Tacca, Cycas species are alternatives because they require multiple additional processing steps to remove toxins that are not present in the preferred species. Abbott [11] reports that Hawaiians pound, salt, or otherwise process algae to make it edible or palatable. Similar processes are required for some other wild species [8] that make them less desirable.

\section{Oceania (Near and Remote)}

The focus of this paper is on the wild foods that were traditionally eaten within the geographic area of Remote Oceania prior to colonization contact from Europeans. Oceania encompasses the islands of the tropical Pacific Ocean through New Guinea, Australia and New Zealand. The terrestrial biological core is a holdout for marsupials with only relatively recent invasions by mammals, including humans. Plant diversity is mostly a mixture of a series of invasions from the Gondwana Australian continent and SE Asian Borneo centers of diversity, with smaller contributions from mainland Asia. These converge within New Guinea and the Philippines forming rich floras. Subsequently, these floras have distributed eastward, island hopping into the Pacific basin with a resulting dramatic attenuation of species richness and diversity from west to east [12].

Biogeographically, Oceania has been divided into two functional areas, Near and Remote Oceania [13] (Fig. 1). Near Oceania was settled around 50000 years ago by pre-agricultural, hunter-gatherer people [14] with certain domesticates such as dogs [15] not arriving until 5000 years ago. Subsequently, they participated in domestication of many wild plant species within the region [16]. Around 5000 years ago, Austronesian language speakers invaded Near Oceania from areas of eastern Asia [17-19]. They introduced new agricultural practices, maritime technologies and perspectives, and alternative ways of perceiving the environment. Their relatively rapid expansion then led into Remote Oceania where they become the first settlers [20] expanding in pulses until reaching all of Eastern remote Oceania by 1000 years ago [21]. Remote Oceania includes islands to the north and south of "the geographic" Solomon Islands (Vanuatu, New Caledonia, Palau, Federated States of Micronesia), and the Pacific islands to the east beginning with the Santa Cruz Islands, almost until the Americas (all of Micronesia and Polynesia; Fig. 1).

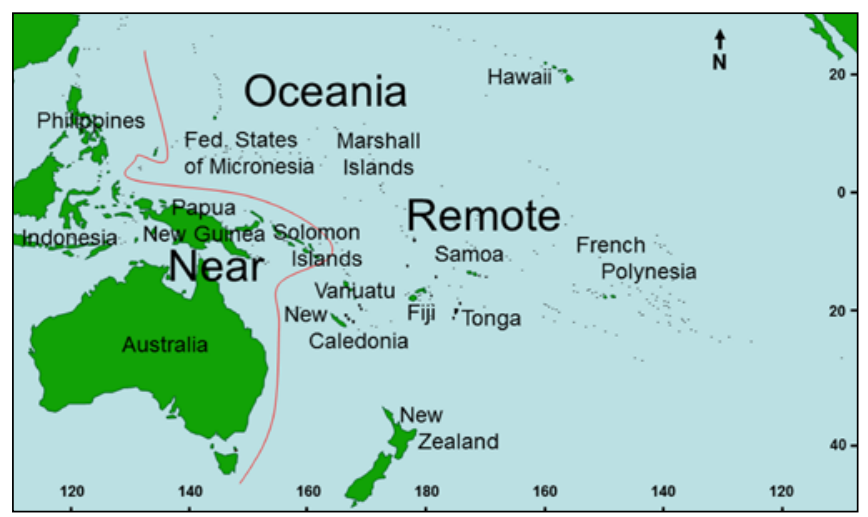

Fig. 1 Near and Remote Oceania separated by red line.

Large birds [22] and fruit bats [23] are important parts of the pre-human diversity in Oceania, especially Remote Oceania. These animals selected for plants with larger fruits and nuts, and were also the animals responsible for distribution of some species across and between islands. These plants would then have been good targets for possible human foods. For the most part, in Remote Oceania there are no terrestrial mammals and very few reptiles. Insectivorous and fruit bats are common in some but not all islands and atolls. Sea-birds and flightless birds, including some that were quite large, were once common. However, species diversity is generally low, based in part upon on strand organisms distributed by the oceans and common to the tropical Indian and Pacific Ocean regions. Other organisms are decedents of rare vicarious events, with some consisting of closely related adaptive radiations. In short, plant and animal diversity is lower than in most other locations where humans have settled. This results in fewer opportunities for wild foods, and because of limited animal life, many plants are not adapted for larger animal dispersal with edible fruits. 


\section{Colonization of Remote Oceania by Austronesians}

About 5000 years ago, Near Oceania was invaded by Austronesian (a language family) speaking people from East Asia $[17,24]$. The Austronesian colonization of Near Oceania resembles the invasion of North America by Europeans. Austronesian settlers dominated interactions with the earlier inhabitants, introducing different technologies, including plant traditions, and adopting Oceanic cultivated and wild plants. The indigenous population and their languages were displaced or incorporated (we don't know how brutal or kind this was). Within a relatively short period of time, the colonists had reached the eastern edges of Near Oceania [25]. They did not stop. Leaving Near Oceania, they had to cross large ocean gaps to the next closest islands.

When they reached the islands of Remote Oceania, they found lands uninhabited by humans. Not only were there no people already in the islands but there were also not preestablished crops that could be taken over. There were, however, some of the same (or similar) wild plant resources that could serve as temporary sustenance until introduced crops could become established. In global history, this is probably one of only two examples of agriculturalists settling lands that had not been previously inhabited by hunter-gatherers [26] or other agriculturalists (the other example is the Viking settlement of Iceland [27]).

It is not entirely clear what the life ways were like of the first people to explore Remote Oceania [28]. However, it is almost certain that they practiced some form of agriculture, supplementing their diets with hunting and gathering of wild foods [29]. Kirch [30] describes first landfalls in parts of Remote Oceania as "Arriving in double-hulled canoes propelled by sails of woven mats, they had followed the flightways of the golden plover in search of unknown lands. The canoes held a precious cargo necessary to reestablish life on new landfalls: bundles of living taro shoots, breadfruit seedlings, and slips of sugarcane, along with other plants to establish new gardens. A floating menagerie of pigs, dogs, and chickens wallowed about in the bilge water. Little rats the Polynesians called kiore, the size of a house mouse, either hid themselves in the cargo or may have been taken along on purpose as a food source. A Polynesian Noah's Ark, bound for the unknown". Their diet possibly focused on Colocasia [31], or a combination of Dioscorea/Musa sp./Amorphophallus paeoniifolius (Dennst.) Nicolson/Tacca leontopetaloides (L.) Kuntze/Pueraria montana (Lour.) Merr. var. lobata (Willd.) Maesen \& S. M. Almeida ex Sanjappa \& Predeep [32]. Yen [33] has argued that the indigenous subsistence systems in the Western Pacific (interface region of Near/Remote Oceania) consisted of annual plant cultivation (with emphasis on root crops); arboriculture (trees and perennials); animal husbandry (pigs, chickens, dogs); and hunting and gathering (fish, birds, medicinals, raw materials). Agriculturalists would have been limited to wild foods during the initial stages of colonization, probably implying a recurring need to explore wild food resources (mostly marine) until agricultural crop cycles became established.

The combination of: $(i)$ starch produced through swampbased vegeculture of root crops; (ii) lipid/protein produced through arboriculture of large seeds; (iii) wild-collected vegetables, typifies the experience that colonists of Remote Oceania would have experienced in Near Oceania. Animal protein was likely limited with domesticated sources being pigs, chickens, dogs, and rats. Wild animal protein came primarily from fish and secondarily from birds, turtles, and bats (as well as native rats and possums in Near but not Remote Oceania).

\section{Classification of food}

The ways that people think about food, plan for food production, and classify plants and foods shape the results of their efforts. In order to develop a picture of how decisions were made, we must understand the emic classification system of Austronesian languages. Austronesian languages in general apply classifications recognizing plants, some with specific terms [34], and others with implied terms. A Proto Oceanic reconstructed language includes terms for many cultivated plants and some wild plants [35].

Two sets of Proto Oceanic terms are important for understanding "wild" plant foods in Oceania. The specific terms vary and are less important than the overall pattern [33]. First, there is a set of cognitive terms that are used to spatially and functionally arrange the world of plants. Natural or old primary vegetation is opposed to gardening areas. Swamps, lagoons, and riparian zones are important subsets of natural vegetation, while gardens and other locations where plants are tended may be divided into several categories following natural vegetation succession cycles that result from conversion of primary vegetation into gardens [36]. The products of these different vegetation categories may be termed as wild or not, with adjectives that often refer to source areas (e.g., from forests, swamps).

Second, meals of Oceanic peoples include two primary categories of ingredients: starches (mostly roots and rhizomes) and other (vegetables, meats) [37]. Food is often discussed as being an interchangeable term with starches [38]. The author has experienced many traditional meals in Oceania consisting entirely of one or more starch sources, confirming this perspective. Therefore, if primary starches were unavailable, Oceanic people would first look for wild starch sources before looking to other sources of sustenance. Ross [39] has in fact pointed out that in many Oceanic languages the verb "to eat" literally or implicitly refers to eating starchy foods. A tertiary category of non-meal foods is widely used as well. This category is raw fruit and raw fish [37].

An additional concern about classifications is the synonymy between circumscriptions of plants that are labeled with scientific names and the circumscriptions for plants in local languages [40]. There are undoubtedly many species that are recognized by science that are grouped into a single taxon by local people. Sometimes this is due to lack of exposure to more than one species at the same time (resulting in lumping of similar species), while in other cases, the uses or other culturally important indicators do not support a distinction with different names (and therefore only one name is applied to several). A different situation can occur with highly used, often cultivated plants. In this case, distinct species level names are applied by local people, and scientists lump together diversity that is not recognized by science [41].

\section{Growing and using plants}

Classification systems for plants and environments are bound into relationships with understandings of how and where plants grow. These forms of knowledge are reinforced through positive feedback cycles as plants are observed and used. Complicating the focus of this paper is the nature of cultivated plants that were introduced by the early settlers into Remote Oceania. Root crops and some vegetables are grown using vegetative cuttings. Tree seed/fruit crops in Remote Oceania are grown mostly by seeds but sometimes from root suckers or vegetative cuttings. We do not know if the colonists 
Tab. 1 Cultivated food plants that were introduced into Remote Oceania prior to European contact.

Major part consumed

\section{Scientific name}

English vernacular

\begin{tabular}{ll}
\hline Fl \\
F \\
\\
\\
F \\
F \\
F
\end{tabular}

\section{Wild in Near and Remote Oceania (65+)}

Auricularia cornea Ehrenb.

Ear fungus

F

Barringtonia spp.

Cut nut

Se

Blechnum spp.

Bruguiera gymnorhiza (L.) Savigny

Bruguiera spp.

Burckella obovata (G. Forst.) Pierre

Canarium spp.

Caulerpa racemosa (Forsskål) J. Agardh

Claoxylon spp.

Corynocarpus spp.

Cyathea spp.

Cycas circinalis L.

$\begin{array}{ll}\text { Orange mangrove } & \mathrm{F} \\ \text { - } & \mathrm{F}\end{array}$

Red silkwood

F

$-$

Cycad

Cyclosorus spp.

Cyrtosperma merkusii (Hassk.) Schott

Dennstaedtia samoensis (Brack.) Moore

Swamp taro

Diplazium spp.

Dracontomelon spp.

Dragon plum

S

Wild fig

Ficus spp.

L

Finschia chloroxantha Diels

Geniostoma rupestre J. R. Forst. \& G. Forst.

Gnetum gnemon L.

Gracilaria spp.

Halymenia spp.

Haplolobus floribundus (K. Schum.) H. J. Lam

Heritiera littoralis Aiton

Hornstedtia scottiana (F. Muell.) K. Schum.

Horsfieldia spp.

Inocarpus fagifer (Parkinson ex Zollinger) Fosberg

Laportea spp.

Maesa spp.

Mangifera spp.

Marsdenia tenacissima (Roxb.) Moon

Metroxylon warburgii Becc.

Morinda citrifolia L.

Musa spp.

Musa troglodytarum L.

Myristica spp.

Nypa fruticans Wurmb

Ochrosia elliptica Labill.

Omphalea spp.

Pandanus spp.

Pandanus tectorius Parkinson

Parartocarpus beccarianus Baill.

Pisonia grandis $\mathrm{R}$. Br.

Planchonella obovoidea H. J. Lam

Pleocnemia spp.

Polyscias scutellaria (Burm. f.) Fosberg

Pometia pinnata J. R. Forst. \& G. Forst.

Pouteria spp.

Pritchardia spp.

Pseuderanthemum spp.

Rhizophora apiculata Blume

Rubus moluccanus L.

Schleinitzia spp.

Solanum repandum G. Forst.

Stenochlaena spp.

$$
-
$$$$
-
$$$$
\text { - } \quad \text { F }
$$

Lookingglass tree

Tahitian chestnut

Wild mango

- $\quad$ L

Sago

Indian mulberry

Wild banana

Wild nutmeg

Nipa

$\mathrm{L}$

$-$

Screw pine $\quad F$

Screw pine $\mathrm{F}$

$-\quad$ F

-

L

Balfour's aralia L L

Island lychee $\mathrm{F}$

Egg fruits $\quad F$

L

L

F

Molucca raspberry $\mathrm{F}$

Pacific tomato F 
Sterculia spp.

Syzygium clusiifolium (A. Gray) Müll. Stuttg. Syzygium spp.

Terminalia catappa $\mathrm{L}$.

Terminalia spp.

Thelypteris spp.

Ulva spp.

Wollastonia biflora (L.) DC.

Wild in Remote and not Near Oceania (1?)

Rhizophora mangle L.

Red mangrove

Often encountered in cultivation in Remote Oceania (16)

Abelmoschus manihot (L.) Medik.

Citrus grandis (L.) Osbeck

Slippery cabbage

Pomelo

Coconut

Taro

Colocasia esculenta (L.) Schott

Cucumis melo $\mathrm{L}$.

Musk melon

Turmeric

Greater yam

Lesser yam

Dioscorea esculenta (Lour.) Burkill

Dioscorea nummularia Lam.

Homalomena pendula (Blume) Bakh.f.

Ipomoea aquatica Forssk.

Ipomoea batatas (L.) Lam.

Lablab purpureus (L.) Sweet

Musa acuminata $\times$ balbisiana Colla

Saccharum edule Hassk.

Saccharum officinarum $\mathrm{L}$.
$\mathrm{Fl}$

Sweet potato

Hyacinth bean

Banana

Pitpit

Sugar cane

\section{F}

F

$\mathrm{Rh}$

$\mathrm{Se}$

$\mathrm{Se}$

S

S

Often encountered as feral in Remote Oceania (18+)

Aleurites moluccana (L.) Willd.

Candlenut

Giant taro

$\mathrm{Rh}$

Se

Alocasia macrorrhizos (L.) G. Don

Amorphophallus paeoniifolius (Dennst.) Nicolson

Elephant foot yam

Archidendron spp.

Pili nut

$\mathrm{Ti}$

Air potato

Five-leaf yam

Rukam

Sago

Metroxylon spp.

Pueraria montana (Lour.) Merr. var. lobata (Willd.) Kudzu

Maesen \& S. M. Almeida ex Sanjappa \& Predeep

Solanum viride Spreng.

Green nightshade

Hog plum

Spondias dulcis Parkinson

-

Syzygium corynocarpum (A. Gray) Müll. Stuttg.

Syzygium malaccense (L.) Merr. \& L. M. Perry

Mountain apple

Pacific arrowroot

Shampoo ginger

Zingiber zerumbet (L.) Roscoe ex Sm.

Breadfruit

F

Cut nut

Se

$\mathrm{F}$

$\mathrm{Rh}$

$\mathrm{Rh}$

$$
\begin{aligned}
& \mathrm{R} \\
& \mathrm{R} \\
& \mathrm{R}
\end{aligned}
$$

$\mathrm{R}$ Se

$\mathrm{R}$

$\mathrm{R}$

$\mathrm{R}$

F

S

$\mathrm{R}$

$\mathrm{L} \quad \mathrm{Rh}$

Barringtonia edulis Seem.

Only English names are given since most have many different local vernacular names. F - fruit or fruit-like reproductive structures; Fl - flowers; L - leaves or leaf-like structures; R - roots; Rh - rhizomes; S - stems or stem tips; Sa - stem sap; Se - seeds. See $[35,43,44]$. 
observed or understood the reproduction of the wild plants that they used both in Near and Remote Oceania. However, it would be consistent with their cultivation activities, if they considered starch sources to be reproduced via vegetative cuttings of herbaceous/rhizomatous plants and tree seed/fruit crops from seeds. If this were the case, then we would expect them to seek out root crops and tree seeds from among the plants of Remote Oceania. A propagation-based wild food plant search image such as this would focus their exploration efforts. Plants that did not fit the desired pattern might not have been used, or propagated, and would be unlikely to become domesticated. However, if discovered anyway, their use would persist as wild resources rather than entering a path toward domestication.

Cox [9] categorized wild plants used in Oceania into three different origins: $(\boldsymbol{i})$ those predating arrival of humans; (ii) those introduced deliberately or inadvertently during the colonization process; (iii) those introduced subsequent to human colonization as part of voyaging/trading. To a certain extent, it is very difficult to distinguish when most of the introduced plants arrived and therefore, with a few exceptions, it is hard to tell which plants are parts of category (ii) verses (iii). Tab. 1 has been sorted into somewhat similar categories with the following distinctions: $(\boldsymbol{i})$ those predating arrival of humans that are widely distributed (in Near and Remote Oceania) as wild plants (and therefore accessible to people prior to entering Remote Oceania) - indigenous wild plants; (ii) those distributed in Remote Oceania but not in Near Oceania (implying that these would be new) - endemic wild plants; (iii) those distributed in Near but not Remote Oceania prior to human colonization of Remote Oceania (implying that these were deliberately or inadvertently introduced) - introduced wild plants, and three categories of cultivated plants that are important to distinguish within this process; (iv) those domesticated in Near Oceania (or elsewhere outside of Remote Oceania) that were introduced prior to European contact and are largely grown as non-wild, cultivated food plants; $(\boldsymbol{v})$ those that have become feral and are often not actively cultivated; ( $\boldsymbol{v i}$ ) cultivated plants that were domesticated from wild plants within Remote Oceania. The last category is essential for understanding the ingenuitive nature of the colonizers of Remote Oceania, and is difficult to distinguish because of the fine line between cultivation and wild. There is surely a continuum of plants from those receiving no tending whatsoever, to those that have either some level of human selection pressure and cultivation, to those that are clearly cultivated.

\section{Inventory of wild plants in Remote 0ceania}

Names and distributions of cultivated and wild food plants that are used on islands at the boundary between Near and Remote Oceania have been brought together using studies of food plants from the region. While published literature [8,35,42-44] serves as the basis for much of the following discussion, the author's own published and unpublished interviews with indigenous communities in a wide variety of Oceanic locations inform specific details that are not easily found in the literature.

Species in genera with overlapping common names (more than one species with the same common name) have been lumped and only listed under the scientific genus. When multiple common names were reported for several species but there was partial overlap, then these were also lumped under the generic scientific name.

\section{Results}

More than 100 taxa are conservatively estimated to have been involved in the successful colonization of Remote Oceania. The majority of these (more than 65\%), are wild plants with broad distributions across Oceania spanning the boundary between Near and Remote Oceania. More than 34\% of plants were cultivated at one time or another. Only two food plants appear to have been domesticated within Remote Oceania.

In addition to those listed in Tab. 1, many modern introduced cultigens may also appear to be semi-cultivated or feral and therefore used as "wild" resources today. These include: Allium cepa L., Capsicum annuum L., Carica papaya L., Mangifera indica L., Manihot esculenta Crantz, Passiflora edulis Sims, Passiflora foetida L., Psidium cattleyanum Sabine, Psidium guajava L., Psophocarpus tetragonolobus (L.) DC., Solanum granuloso-leprosum Dunal, Solanum melongena L., Tamarindus indica L., Trichosanthes cucumerina L., Vigna unguiculata (L.) Walp., Xanthosoma spp. While not part of this assessment, the selections made are often consistent with ancient food choices: trees with edible fruit and starchy root crops.

\section{Discussion}

\section{Near versus Remote 0 ceanic wild plant use}

Wild plants used in Near Oceania are dramatically more diverse $[8,35]$ than those in Remote Oceania and even when present in Near and Remote, fewer are used in Remote. This phenomenon can easily be observed within Solomon Islands where part of the islands are Near and part Remote. As an example, Stenochlaena laurifolia Presl. is widely considered as a food in Near Oceania (Malaita, Makira, Guadalcanal, Papua New Guinea [45]) but is not eaten in Remote Oceania (Santa Cruz Islands) even though it grows there.

Some species are wild in western parts of Remote Oceania and introduced in the east. There is, in fact, an attenuation with more wild and cultivated species in the west than east. This implies that all were not moved together, or did not equally persist, and possibly that they were discovered or introduced at different times and places. Certainly there are few that show evidence of being moved from east to west, the notable exception being Ipomoea batatas (L.) Lam.

Two food plants that were domesticated in Remote Oceania are Artocarpus altilis (Parkinson) Fosberg and Barringtonia edulis. In both cases, there are similar, related species of trees that are used as wild foods in Near Oceania. The case of $A$. altilis is particularly interesting because across Remote Oceania it is grown in a mixed range of almost wild (feral) to completely cultivated (dependent on humans for vegetative propagation). Furthermore, it has become a critical food resource for several cultural groups, perhaps enabling long-term settlement of some marginal islands.

The dominant cultivated foods of Near Oceania are herbaceous, starchy root/rhizome crops [e.g., Alocasia macrorrhizos (L.) G. Don, Colocasia esculenta (L.) Schott, Cyrtosperma merkusii (Hassk.) Schott, Dioscorea spp.] augmented with trees producing lipid/protein-rich seeds [e.g., Barringtonia spp., C. indicum L., Cocos nucifera L., Inocarpus fagifer (Parkinson ex Zollinger) Fosberg, Terminalia spp.]. These plants all thrive in wet, often swampy environments. Classic agriculture based 
on herbaceous grass and legume seeds was absent. However grasses (Saccharum officinarum L., Saccharum edule Hassk.), and legumes [I. fagifer, Lablab purpureus (L.) Sweet, and Pueraria montana (Lour.) Merr. var. lobata (Willd.) Maesen \& S. M. Almeida ex Sanjappa \& Predeep] were all grown and used differently than grass/legume agriculture in Asia, Europe, Africa, or North America, encouraging a different perspective on what food plants should look like.

Near Oceanic food production also included Cordyline fruticosa (L.) A. Chev. (roots and leaves) and Musa acuminata $\times$ balbisiana Colla (fruit and leaves), that were probably used as much for food processing (leaves) as they were for food sources (respectively roots and fruit). Metroxylon spp. trees were also harvested in some locations for their stem starch, however, their leaves served as superior thatching material making them more valuable in most locations for that purpose.

Leaves from Abelmoschus manihot (L.) Medik. and C. esculenta were the only commonly cultivated leafy green vegetables consumed. Most other vegetables and fruit were collected from mainly wild sources.

\section{Nuts and seeds}

Fruits of several trees were grown as staple nut/seed foods in parts of Oceania, feral or wild food in other parts, and are absent in others. This pattern is generally from west to east crossing the Pacific. Examples of trees that were domesticated in Near Oceania and then dispersed across Remote Oceania include: Aleurites moluccana (L.) Willd., some Barringtonia spp., Canarium indicum, C. nucifera, Finschia chloroxantha Diels, Haplolobus floribundus (K. Schum.) H. J. Lam, Heritiera littoralis Aiton, I. fagifer, and some Terminalia spp. The seeds of Gnetum gnemon L. and related members of this genus are also eaten as nuts but are technically not "fruits" (Gnetum leaves are also eaten). For many of these plants, it is difficult to tell a difference between tended (domesticated?) and untended wild populations. It is likely that these have continued to interbreed diluting any human selection activities. It is also possible that other species of Canarium, and Barringtonia were possibly domesticated within Remote Oceania but in modern times have become feral with disuse. Surely early recognition of these as possible foods was based upon experience eating related members of the same genera in Near Oceania.

\section{Other fruit}

Fleshy fruited species were likely the most biologically diverse wild food resource available to settlers of Remote Oceania. Citrus grandis (L.) Osbeck has been argued as being an introduced species [31] however, linguistic data supports possible ancient distribution of it or another Citrus species [35]. Burckella obovata (G. Forst.) Pierre, Flacourtia rukam Zoll. \& Moritzi, Pometia pinnata J. R. Forst. \& G. Forst., Syzygium clusiifolium (A. Gray) Müll. Stuttg., Syzygium malaccense (L.) Merr. \& L. M. Perry, and Spondias dulcis Parkinson are fruit trees that are widely grown and consumed regularly. Many Pandanus fruit are edible, having some amount of starch or sweet juice on the inner part of each compound fruit "key". Some Pandanus (and Freycinetia) spp. may also have more fleshy fruit that is entirely edible, but these are not often mentioned. Some edible fruit are either rarely consumed or only discussed as famine foods (e.g., Corynocarpus spp., Parartocarpus beccarianus Baill.).

Rhizophora mangle L. has a complex and controversial history. It appears to be the only wild food plant in Oceania that originated in the Americas. Steele [46] has argued that it was naturally distributed into Remote Oceania with possible subsequent movement by people toward the west. However, other species of Rhizophora are widely distributed across Oceania, but were only rarely reported as eaten.

While not "fruit", the reproductive structures of wild fungi were harvested and eaten from several kinds of trees that serve as indicators of edibility. Some trees (e.g., Metroxylon) are felled and damaged to promote production of edible fungi. A wide variety of mushrooms (Ascomycota and Basidiomycota) are eaten in Near Oceania (e.g. [8]), but few are consumed in Remote Oceania except in New Zealand [47]. The only widely eaten fungus is Auricularia cornea Ehrenb. Ethnomycological studies in the Western Pacific region are limited and there is very little information identifying the taxa that are being consumed.

A large number of the wild food plants are fruits and leafy green vegetables. It would be very interesting to examine the nutritional contributions that these make, as well as the roles that they might play in childhood development and disease prevention (e.g., [48]).

\section{Vegetables}

Ross [39] has provided an excellent overview of green vegetables consumed in Oceania. The most commonly consumed are young leaves of Abelmoschus manihot and Colocasia esculenta. The latter includes wild and cultivated populations in Near Oceania, and cultivated and feral populations in Remote Oceania. Ipomoea aquatica Forssk. was likely domesticated in Near Oceania, but it is difficult to determine if it was introduced into Remote Oceania in ancient times. It is an important leafy green vegetable in some communities and would appear to be an excellent candidate for distribution. It may have been displaced more recently by the introduction of Ipomoea batatas from the Americas which has been eaten as much for its leaves (much like I. aquatica) as for its starchy roots.

Ferns were an important secondary category of edible leaves. Fern species are frequently endemic to particular islands or archipelagos, but genera are widespread and probably served as functional ethnotaxa (e.g., Blechnum, Cyathea, Cyclosorus, Dennstaedtia, Diplazium, Thelypteris). All of these leaves are generally consumed as young, often unfurled leaves that are steamed or boiled. "Salads" do not appear to have been part of traditional practices. All of the ferns are wild harvested.

Marine (as terrestrial) species richness drops off from Near through Remote Oceania [49]. However, there appears to be greater use of algae as a food resource within Remote than Near Oceania [50]. A few algae were widely consumed as foods or condiments [e.g., Caulerpa racemosa (Forsskål) J. Agardh, Halymenia spp., Gracilaria spp., Ulva spp.; e.g., [51]].

Leaves of many plants are incidentally edible at some growth stage, probably being eaten primarily when more desirable foods were in short supply. Ficus spp., Gnetum spp., Morinda citrifolia L., Polyscias spp., and Pseuderanthemum spp. are commonly reported as eaten. In each case, it is usually younger leaves that are preferred, sometimes still in bud. Of these, Gnetum is most common in little disturbed forests, while edible Ficus and M. citrifolia are common in coastal strand forests and adjacent open areas. Polyscias and Pseuderanthemum are common garden and village plants that may represent old settlements when found outside of these areas. Laportea and Pisonia leaves are commonly reported as food for pigs, and less often for humans. Although M. citrifolia is 
widespread in Near and Remote Oceania, reports of eating leaves are spotty, with some people even denying that they are edible (the same is incidentally true for the horrid smelling M. citrifolia fruit).

Most palms have an edible "palm heart" consisting of the growing apical meristem and adjacent young leaf material. This is true of all species native to Remote Oceania. However, only a few are regularly eaten, such as Metroxylon, Nypa and Pritchardia because the trees are cut down and used for other purposes (e.g., leaf thatch). Cocos nucifera hearts may also be eaten but because of the value of the tree for other purposes, they were not commonly consumed.

Alpinia novae-hiberniae B. L. Burtt \& R. M. Sm., Cyathea spp., Metroxylon spp., Wollastonia biflora (L.) DC. each have partially edible stems. Traditional consumption levels of these are higher in New Guinea (Near Oceania) and taper off to the east and north with a lack of recognition that they are edible in the many locations where they grow. Saccharum officinarum is a stem crop domesticated in New Guinea that maintains its use across its distribution into Remote Oceania. However, its leaves became important as thatch in parts of Remote Oceania while this use is not mentioned in Near Oceania where there were many superior thatch sources.

\section{Insects collected from plants}

Several plants served as the food source for edible insect larvae. Many palms including Metroxylon spp., Pritchardia pacifica Seem. \& H. Wendl., and Veitchia spp. are damaged so that insects will lay their eggs in them. Timing is important if the lipid-rich larvae are to be collected as food before they mature. Caryota rumphiana Mart. Stems host insect larvae that are eaten. It is unclear when this palm may have been introduced from Near to Remote Oceania. Other plants are either grown, encouraged to persist, or periodically checked for the presence of edible insect larvae.

\section{Wild food plants when cultivation fails}

The colonists of Remote Oceania generally encountered environments that were both supportive of their cultivated plant tool kit and contained familiar wild plants. However, some environments were climatically or ecological restricted (atolls - e.g., [52,53]) and others climatically marginal (Hawaiian islands - e.g., [54,55]). One major settlement was the most extreme that has persisted. This was the colonization of the massive uninhabited area of Aotearoa (New Zealand). It exceeds in area all of the rest of Remote Oceania combined, but it is so far to the south that much of the plant and animal life is different from that previously encountered by Austronesian settlers. Crowe [56] attempted to identify all possible wild plant foods in Aotearoa. Crowe conducted a field experiment, attempting to feed himself for an extended period only with native plants. His report is not encouraging, noting that on some days he was unable to find any plants that were edible. Even after including about 160 plants, it is painfully obvious that survival on wild plants in New Zealand would be difficult, especially for people primarily interested in starchy roots and protein-rich seeds/nuts. Fruit, mushrooms and ferns appear to be common, but do not seem to be ready substitutes for traditional dietary preferences. In the end, cultural expectations may be what drives the selection of foods and the sharing of what is learned with others. The original New Zealand colonists were highly resourceful, but it must have been a very difficult process to survive on such unusual fare.

\section{Problems with this assessment}

Because it is difficult to determine if and when a plant was introduced, it is possible to identify plants as being important ancient wild food plants, that in fact were not present in the past. Two methods have been used to reduce the number of false leads: linguistic analysis of plant names (e.g., [35]), and analysis of plant relationships with wild relatives [57]. Both of these have problems. For example, it is possible to produce linguistic reconstructions for plants that have well known recent introductions such as Psidium guajava or Carica papaya. In each case, this is probably just an indication that the plants were introduced from related sources and arrived with names in common. Plants in Tab. 1 that could suffer from this problem include Lablab purpureus, Ipomoea aquatica, and Citrus grandis. In each case, there is reason to believe, based upon relationships with other species of plants that these may be more recent introductions into Remote Oceania. Likewise, Terminalia catappa and Bruguiera gymnorhiza (L.) Savigny may be examples of plants that have actually been introduced by humans over much or part of Remote Oceania even though they are related to other plants within the region and have mechanisms for naturally dispersing through the region.

Scientists have "learned" biases about the history of plants. Those working in the Pacific "know" certain biogeographic facts that are based on scientific tradition rather than experimental or other positive evidence. For example, several widely distributed strand species [Aleurites moluccana, Cocos nucifera, Inocarpus fagifer, Morinda citrifolia, Pandanus tectorius Parkinson, P. pinnata, Polyscias scutellaria (Burm. f.) Fosberg] are thought to be distributed in eastern and northern parts of Remote Oceania via humans, despite each having natural dispersal capabilities via marine currents or fruit bats. The simple fact is that for most of these, we do not know how or when they were dispersed from island to island and assumptions are made, usually on a combination of local comments, and early botanical collection information that is surely incomplete.

\section{Conclusions}

Wild food plants in Remote Oceania have a complex history. The presence or absence of taxa as well as selection of previously existing taxa, is driven by cultural factors including expectations about what food should be and aesthetics (taste, texture, smell) rather than potential nutrition.

As an unusual region, originally colonized by agriculturalists, it is likely that there were many untapped wild food plants that would have been discovered by hunter-gathers if colonization had proceeded differently.

The majority of species used as foods in the initial colonization of Remote Oceania were wild foods, and most of these were used as leafy vegetables and fruits. The wild food plants mostly served as supplements to domesticated species, although there were a few that can be used as substitutes for traditional staples. The implication of this situation is that although some plants are managed as reserves or substitutes for lean times, the majority of wild foods serve other than primary caloric nutritional needs.

Based on this brief assessment, it should be expected (hypothesized) that within a particular culture, the selection of plants for domestication from among those discovered will strongly reflect the characteristics of the earliest founding domesticated foods. Plants that are drafted into roles as 
"famine foods" or wild supplemental foods, will be of two types: those that provide similar food products but have some deficiency (such as taking longer to process), and those that do not provide similar food products, but have supplementary benefits that are realized even when there is no stress on the food supply.

\section{Acknowledgements}

Thanks to Piet Lincoln and Kawika Winter for many discussions of the colonization of Remote Oceania. Thanks to Valerie McClatchey for commenting on drafts of this document.

\section{References}

1. Jackson F. The coevolutionary relationship of humans and domesticated plants. Am J Phys Anth. 1996;101(23 suppl):161-176. http://dx.doi. org/10.1002/(SICI)1096-8644(1996)23+<161::AID-AJPA6>3.0.CO;2-8

2. Winter K, McClatchey $\mathrm{W}$. The quantum co-evolution unit: an example of 'awa (kava-piper methysticum G. Foster) in Hawaiian culture. Econ Bot. 2009;63(4):353-362. http://dx.doi.org/10.1007/s12231-009-9089-0

3. Fehr WR. Principles of cultivar development. Theory and technique. Ames IA: Macmillan; 1991. (vol 1).

4. Anderson E. Plants, man and life. Boston MA: Little, Brown; 1952.

5. Sauer CO. Agricultural origins and dispersals. New York NY: American Geographical Society; 1952.

6. Bettinger RL. Hunter-gatherers: archaeological and evolutionary theory. New York NY: Plenum Press; 1991.

7. Huss-Ashmore R, Johnston SL. Wild plants as cultural adaptations to food stress. In: Etkin N, editor. Eating on the wild side: the pharmacologic, ecologic and social implications of using noncultigens. Tucson AZ: University of Arizona Press; 1994. p. 62-82.

8. Henderson CP, R HI. A guide to the useful plants of Solomon Islands. Honiara: Ministry of Agriculture and Lands; 1988.

9. Cox PA. Wild plants as food and medicine in Polynesia. In: Etkin N, editor. Eating on the wild side: the pharmacologic, ecologic and social implications of using noncultigens. Tucson AZ: University of Arizona Press; 1994. p. 102-113.

10. Paull RE, Tang CS, Gross K, Uruu G. The nature of the taro acridity factor. Postharvest Biol Tec. 1999;16(1):71-78. http://dx.doi.org/10.1016/ S0925-5214(98)00099-4

11. Abbott IA. Lảau Hawai'i: traditional Hawaiian uses of plants. Honolulu: Bishop Museum Press; 1992.

12. MacArthur RH, Wilson EO. The theory of island biogeography. Princeton: Princeton University Press; 2001. (Monographs in Population Biology; vol 1).

13. Green RC. Near and remote Oceania: disestablishing "Melanesia" in culture history. In: Bulmer R, Pawley A, editors. Man and a half: essays in Pacific anthropology and ethnobiology in honour of Ralph Bulmer. Auckland: Polynesian Society; 1991. p. 491-502. (Memoirs of the Polynesian Society).

14. Kayser M. The human genetic history of Oceania: near and remote views of dispersal. Curr Biol. 2010;20(4):R194-R201. http://dx.doi.org/10.1016/j. cub.2009.12.004

15. Oskarsson MCR, Klutsch CFC, Boonyaprakob U, Wilton A, Tanabe Y, Savolainen P. Mitochondrial DNA data indicate an introduction through Mainland Southeast Asia for Australian dingoes and Polynesian domestic dogs. Proc R Soc B. 2011;279(1730):967-974. http://dx.doi.org/10.1098/ rspb.2011.1395

16. Harris DR, Bellwood P. The origins and spread of agriculture in the
Indo-Pacific region: gradualism and diffusion or revolution and colonization. In: The origins and spread of agriculture and pastoralism in Eurasia. London: University College London Press; 1996. p. 465-498.

17. Blust RA. The Austronesian languages. Canberra: Australian National University Press; 2009.

18. Goff J, McFadgen BG, Chague-Goff C, Nichol SL. Palaeotsunamis and their influence on Polynesian settlement. Holocene. 2012;22(9):10671069. http://dx.doi.org/10.1177/0959683612437873

19. Wilmshurst JM, Hunt TL, Lipo CP, Anderson AJ. High-precision radiocarbon dating shows recent and rapid initial human colonization of East Polynesia. Proc Natl Acad Sci USA. 2010;108(5):1815-1820. http://dx.doi. org/10.1073/pnas.1015876108

20. Gray RD, Drummond AJ, Greenhill SJ. Language phylogenies reveal expansion pulses and pauses in pacific settlement. Science. 2009;323(5913):479-483. http://dx.doi.org/10.1126/science.1166858

21. Matisoo-Smith E. Origins and dispersals of Pacific peoples: evidence from mtDNA phylogenies of the Pacific rat. Proc Natl Acad Sci USA. 2004;101(24):9167-9172. http://dx.doi.org/10.1073/pnas.0403120101

22. McConkey KR, Meehan HJ, Drake DR. Seed dispersal by Pacific pigeons (Ducula pacifica) in Tonga, Western Polynesia. Emu. 2004;104(4):369376. http://dx.doi.org/10.1071/MU03060

23. Cox PA, Elmqvist T, Pierson ED, Rainey WE. Flying foxes as strong interactors in South Pacific island ecosystems: a conservation hypothesis. Conserv Biol. 1991;5(4):448-454. http://dx.doi.org/10.1111/j.1523-1739.1991. tb00351.x

24. Bellwood P. A hypothesis for Austronesian origins. Asian Persp. 1988;26(1):107-117.

25. Oppenheimer $\mathrm{S}$. The "express train from Taiwan to Polynesia": on the congruence of proxy lines of evidence. World Archaeol. 2004;36(4):591-600. http://dx.doi.org/10.1080/0043824042000303773

26. Jennings JD. The prehistory of Polynesia. Canberra: Australian National University Press; 1979.

27. Vésteinsson O, McGovern TH, Keller C. Enduring impacts: social and environmental aspects of Viking age settlement in Iceland and Greenland. Arch Island. 2002;2:98-136.

28. Burley D, Weisler MI, Zhao JX. High precision U/Th dating of first polynesian settlement. PLoS One. 2012;7(11):e48769. http://dx.doi.org/10.1371/ journal.pone.0048769

29. Yen DE. Polynesian cultigens and cultivars: the question of origin. In: Cox PA, Banack SA, editors. Plants, islands, and Polynesians: an introduction to Polynesian ethnobotany. Portland OR: Dioscorides Press; 1991. p. 67-96.

30. Kirch PV. A shark going inland is my chief: the island civilization of ancient Hawai'i. Berkeley: University of California Press; 2012.

31. Barrau J. Les plantes alimentaires de l'Océanie, origines, distribution et usages. An Musée Col Marseille. 1962;7:3-9.

32. Guppy HB. Observations of a naturalist in the Pacific between 1896 and 1899: plant-dispersal. London: Macmillan; 1906. (vol 2).

33. Yen DE. Subsistence to commerce in Pacific agriculture: some four thousand years of plant exchange. In: Predergast HDV, Etkin NL, Harris DR, Houghton PJ, editors. Plants for food and medicine. Kew: Royal Botanic Gardens; 1998. p. 161-183.

34. Evans B. Ethnobotanical classification. In: Ross M, Pawley A, Osmond M, editors. The lexicon of Proto Oceanic: the culture and environment of ancestral Oceanic society. Plants. Canberra: Australian National University Press; 2010. p. 53-84. (vol 3).

35. Ross M, Pawley A, Osmond M, editors. The lexicon of Proto Oceanic: the culture and environment of ancestral Oceanic society. Plants. Canberra: Australian National University Press; 2010. (vol 3).

36. Jansen T, Sirikolo MQ. Petanigaki ta Siniqa ni Lauru. Honiara: Kastom Garden Association; 2010.

37. Pollock NJ. These roots remain: food habits in islands of the Central and Eastern Pacific since western contact. Laie: University of Hawaii Press; 1992. 
38. Barrau J. Witnesses of the past: notes on some food plants of Oceania. Ethnology. 1965;4(3):282. http://dx.doi.org/10.2307/3772988

39. Ross M. Introducing Proto Oceanic plant names. In: Ross M, Pawley A, Osmond M, editors. The lexicon of Proto Oceanic: the culture and environment of ancestral Oceanic society. Plants. Canberra: Australian National University Press; 2010. p. 25-52. (vol 3).

40. McClatchey W. Ethnobiology - basic methods used to document dynamic relationships between peoples, biota and environments, and ways in which this knowledge is represented in languages. In: Thieberger N, editor. The Oxford handbook of linguistic fieldwork. Oxford: Oxford University Press; 2011. p. 281-297.

41. Winter K, McClatchey W. Quantifying evolution of cultural interactions with plants: implications for managing diversity for resilience in socialecological systems. Func Ecosyst Commun. 2008;2(1 special issue):1-10.

42. Mcclatchey W, Thaman R, Vodonaivalu S. A preliminary checklist of the flora of Rotuma with Rotuman names. Pac Sci. 2000;54:345-363.

43. Verheij EWM, Coronel RE. Edible fruits and nuts. In: Faridah Hanum I, van der Maesen LJG, editors. PROSEA: plant resources of South-East Asia. Wageningen: Pudoc; 1991. (vol 2).

44. Whistler WA. Polynesian plant introductions. In: Cox PA, Banack SA, editors. Plants, islands, and Polynesians: an introduction to Polynesian ethnobotany. Portland OR: Dioscorides Press; 1991. p. 41-66.

45. Powell JM. Ethnobotany. In: Paijmans K, editor. New Guinea vegetation. Amsterdam: Elsevier; 1976. p. 106-183.

46. Steele OC. Natural and anthropogenic biogeography of mangroves in the Southwest Pacific [PhD thesis]. Honolulu: University of Hawaii; 2006.

47. Fuller R. Fungi and Polynesia: New Zealand and Cook Island Maori ethnomycology [PhD thesis]. Honolulu: University of Hawaii; 2009.
48. Etkin N. Pharmacologic implications of "wild" plants in Hausa diet. In: Etkin N, editor. Eating on the wild side: the pharmacologic, ecologic and social implications of using noncultigens. Tucson AZ: University of Arizona Press; 1994. p. 85-101.

49. N'yeurt A, South G. Biodiversity and biogeography of benthic marine algae in the southwest Pacific, with specific reference to Rotuma and Fiji. Pac Sci. 1997;51(1):18-28.

50. Abbott IA. Polynesian uses of seaweed. In: Cox PA, Banack SA, editors. Plants, islands, and Polynesians: an introduction to Polynesian ethnobotany. Portland OR: Dioscorides Press; 1991. p. 135-146.

51. Conte E, Payri C. Present day consumption of edible algae in French Polynesia: a study of the survival of pre-European practices. J Polyn Soc. 2006;115(1):77.

52. Merlin M, Capelle A, Keene T, Juvik J, Maragos J. Keinikkam Im Melan Aelon Kein. Plants and environments of the Marshall Islands. Honolulu: East-West Center; 1994.

53. National Biodiversity Team of the Republic of the Marshall Islands. The Marshall Islands: living atolls amidst the living sea. Santa Clara: St. Hildegard Publisher; 2000.

54. Cuddihy LW, Stone CP. Alteration of native Hawaiian vegetation: effects of humans, their activities and introductions. Honolulu: University of Hawaii; 1990.

55. Handy ESC, Handy EG, Pukui MK. Native planters in old Hawaii: their life, lore, and environment. Honolulu: Bishop Museum Press; 1972.

56. Crowe A. Native edible plants of New Zealand. Auckland: Hodder \& Stoughton; 1990.

57. Vavilov NI. Origin and geography of cultivated plants. Cambridge: Cambridge University Press; 1994. 